\title{
PERTUMBUHAN AWAL TANAMAN MIMBA DI NUSA PENIDA DENGAN TEKNIK MANIPULASI LINGKUNGAN
}

\author{
(Early Growth Development of Neem by The Enviromental Manipulation \\ in Nusa Penida)
}

\author{
Ali Setyayudi ${ }^{1} *$, Budi Hadi Narendra ${ }^{2)}$, \& Ryke Nandini ${ }^{3)}$ \\ ${ }^{1,3)}$ Peneliti Balai Penelitian dan Pengembangan Teknologi Hasil Hutan Bukan Kayu \\ Jl. Dharma Bhakti No.7 Langko Lingsar Lombok Barat, NTB \\ Telp (0370) 6573874, fax (0370) 6573841 \\ ${ }^{2)}$ Peneliti Pusat Penelitian Dan Pengembangan Hutan \\ *Email : namaku_stia@yahoo.com
}

\begin{abstract}
Neem can be choosen for the rehabilitation activities in Nusa Penida. For increasing the neem adaptability on the marginal land the environmental manipulation can be apllied by adding the manure, hydrogel, and terrace. To examine the efectivity of the environmental manipulation, therefore, this study reported the early growth of neem as the response of the environmental manipulation. Latin square experimental design was applied in this study with five treatments including the addition of manure, manure + terrace, manure + hydrogel, terrace + hydrogel, and control. The results showed the environmental manipulation treatment increased the growth of neem. The manure and hygrogel treatment gave the higest growth than others; the growth showed twice an control.
\end{abstract}

Keywords : Neem, manure, hydrogel, terrace

\section{ABSTRAK}

Mimba menjadi salah satu jenis yang dapat dipilih untuk kegiatan rehabilitasi lahan kritis di Nusa Penida. Untuk meningkatkan kemampuan adaptasi tanaman mimba dilakukan penelitian manipulasi lingkungan dengan penambahan pupuk kandang, hydrogel, dan pembuatan gulud. Guna mengetahui efektifitas kegiatan manipulasi lingkungan maka penelitian ini akan ditujukan untuk mengetahui adakah peningkatan pertumbuhan tanaman mimba dengan manipulasi lingkungan yang dilakukan. Rancangan percobaan yang digunakan adalah pola latin square dengan lima perlakuan yaitu penambahan pupuk kandang, pupuk kandang+gulud, pupuk kandang + hydrogel, gulud+hydrogel, dan kontrol. Hasil penelitian menunjukkan adanya peningkatan pertumbuhan tanaman mimba akibat adanya kegiatan manipulasi lingkungan. Pemberian pupuk kandang dan hydrogel memiliki peningkatan pertumbuhan tanaman mimba paling besar dibandingkan yang lain yaitu dua kali lipat kontrol.

Kata kunci : Mimba, pupuk kandang, hydrogel, gulud

\section{A. PENDAHULUAN}

Kondisi topografi di Propinsi Bali sebagian besar didominasi oleh perbukitan dan pegunungan. Lahan dengan kemiringan lereng dibawah $40 \%$ sebagian besar berada di bagian tengah Pulau Bali, sedangkan lahan-lahan dengan kemiringan lereng diatas $40 \%$ merupakan daerah perbukitan dan sebagian wilayah Pulau Nusa Penida (Pemerintah
Provinsi Bali, 2010). Salah satu masalah lahan di Pulau Bali adalah lahan kritis dengan luas sekitar 9,1\% dari seluruh luas wilayah Bali. Lahan kritis dalam kawasan hutan terluas berada di Kabupaten Buleleng, sedangkan yang diluar kawasan hutan berada di Kabupaten Klungkung. Kabupaten Klungkung memiliki persentase lahan kritis terbesar sekitar 45\% dari luas wilayahnya dan hampir seluruhnya berada di Kecamatan Nusa Penida. Kondisi lahan di 
Nusa Penida memiliki tutupan lahan yang tandus, gundul dan gersang sehingga saat musim hujan datang, berpotensi terbawa air hujan atau terjadi erosi (Pemerintah Provinsi Bali, 2010).

Topografi di Nusa Penida 73\% berupa perbukitan dengan kemiringan diatas 45\%. Tanahnya bersolum dangkal dan cenderung berbatu. Persediaan air tanah bagi masyarakat juga cukup menjadi permasalahan. Kondisi vegetasi yang ada di Nusa Penida didominasi semak hingga belukar, sedangkan vegetasi tingkatan pohon sebagian besar berada di daerah-daerah tertentu saja. Oleh karena itu perlu dilakukan kegiatan rehabilitasi lahan yang tepat. Tanaman mimba dapat menjadi salah satu alternatif jenis tanaman yang direkomendasikan. Sifat perakaran tanaman mimba yang dalam dan mampu beradaptasi dengan lingkungan yang kritis menjadi salah satu keunggulannya. Dibeberapa tempat di Nusa Penida ditemukan bekas adanya tanaman mimba, sehingga dapat dijadikan indikasi bahwa tanaman mimba mampu hidup dilokasi tersebut. Selain itu secara ekonomi di Bali terdapat perusahaan yang memanfaatkan produk mimba sebagai bahan baku pembuatan produk herbal baik untuk kosmetik, pestisida, pupuk, dan obat-obatan (Indoneem, 2005).

Untuk membantu meningkatkan daya adaptasi tanaman mimba terhadap kondisi lingkungan di Nusa Penida terutama mengatasi kondisi topografi yang miring, kedalaman tanah yang dangkal, dan minimnya jumlah air tanah, maka perlu dilakukan kegiatan manipulasi lingkungan penanaman. Kegiatan manipulasi lingkungan dilakukan pada tahap persiapan lahan yaitu dengan pembangunan gulud untuk mencegah erosi lahan miring dikarenakan guludan dapat memperlambat aliran permukaan atau menyalurkannya dengan kekuatan yang tidak merusak (Arsyad, 2010). Penambahan bahan organik pupuk kandang untuk mengatasi masalah tanah yang dangkal dikarenakan selain menambah unsur hara tanah, pupuk kandang juga mempunyai kemampuan untuk memperbaiki sifat fisik tanah seperti permeabilitas, porositas, struktur tanah, daya menahan air dan kation-kation tanah (Hardjowigeno, 1987). Untuk menambah pasokan air dilakukan penambahan hydrogel dikarenakan mempunyai kemampuan menyimpan air hingga 400 kali massa dan mampu bertahan hingga 2-3 bulan (Rahardjo, 2007).

Kegiatan manipulasi lingkungan ditujukan untuk meningkatkan produktifitas tanaman mimba yang ditanam, melalui pengamatan pertumbuhan tinggi dan diameter terhadap manipulasi lingkungan yang diterapkan.

\section{BAHAN DAN METODE}

\section{A. Lokasi dan Waktu Penelitian}

Penelitian dilaksanakan di Kawasan Hutan Tujuan Khusus (KHDTK) Nusa Penida, Balai Penelitian dan Pengembangan Teknologi Hasil Hutan Bukan Kayu. Secara administrasi lokasi tersebut termasuk dalam Register Tanah Kehutanan (RTK) 28C Desa Suana, Kecamatan Nusa Penida, Kabupaten Klungkung, Propinsi Bali. Kegiatan penelitian diawali pembangunan plot pada tahun 2010 dan dilakukan pengamatan pertumbuhan tanaman mimba hingga tahun 2013 atau selama 3 tahun.

\section{B.Alat dan Bahan}

Bahan penelitian yang dibutuhkan adalah bibit mimba, pupuk kandang, hydrogel, bibit rumput gajah, bibit gamal, pupuk NPK, air dan sampel tanah. Sedangkan peralatan yang digunakan adalah cangkul, meteran, kaliper, ember, timbangan, alat pengukur curah hujan, plastik sampel, dan alat tulis.

\section{Rancangan Penelitian}

Kegiatan manipulasi lingkungan yang diberikan pada saat penanaman tanaman mimba yaitu, pemberian pupuk kandang (P1), pupuk kandang dan gulud (P2), hydrogel dan pupuk kandang (P3), gulud dan hydrogel (P4), serta plot kontrol (P0). Dosis pupuk kandang sebanyak $5 \mathrm{~kg}$ per tanaman, hydrogel sebanyak 5 gr per tanaman, sedangkan guludan dibuat di antara baris tanaman mimba dengan campuran rumput gajah dan gamal. Layout plot perlakuan ditampilkan dalam Gambar 1. 


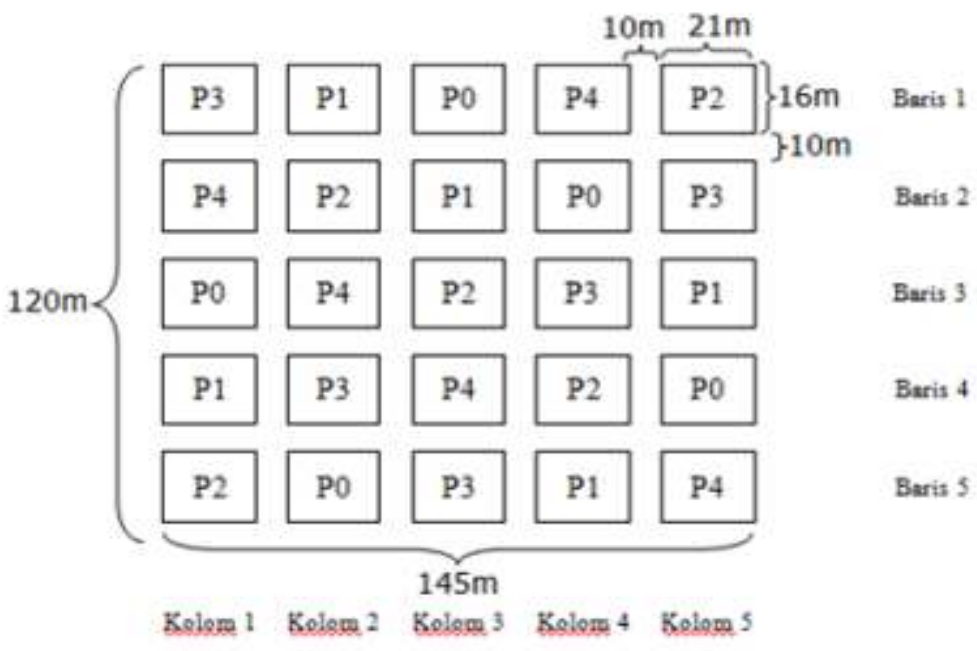

Gambar 1. Layout plot perlakuan penanaman mimba di Nusa Penida, Bali Picture 1. The layout of neem treatment plot in Nusa Penida, Bali

Rancangan penelitian yang digunakan adalah pola latin square dengan lima perlakuan, lima baris dan lima kolom. Dalam setiap plot penanaman terdapat 40 tanaman mimba sehingga total ada 1.000 tanaman mimba. Sedangkan pengamatan pertumbuhan dilakukan dengan intensitas 1 kali per tahun. Parameter yang diukur adalah pertumbuhan tinggi dan diameter batang serta persentase hidup tanaman. Selain pengamatan pertumbuhan tanaman mimba dilakukan pula pengukuran besarnya curah hujan yang terjadi dilokasi penelitian serta pengambilan sampel tanah guna mengukur tingkat kesuburan tanah di lokasi penelitian.

\section{Analisis Data}

Data pertumbuhan tinggi dan diameter tanaman dianalisis secara statistik dengan analisa keragaman untuk melihat variasi antar perlakuannya. Apabila hasil analisa keragaman terdapat perbedaan yang signifikan dilakukan uji lanjut duncan. Analisa statistik dilakukan dengan bantuan software SPSS.15.0. Model matematik yang digunakan adalah sebagai berikut (Sastrosupadi, 2000):

$Y i j k=\mu+T_{i}+B_{j}+K_{k}+€_{i j k}$
Dimana :

$\mathrm{Y}_{\mathrm{ijk}}=$ respon pengamatan dari perlakuan ke-i, baris ke $\mathrm{j}$ dan kolom ke-k

$\mu=$ nilai tengah umum

$\mathrm{T}_{\mathrm{i}}=$ pengaruh perlakuan ke-i

$\mathrm{B}_{\mathrm{j}}=$ pengaruh baris ke-j

$\mathrm{K}_{\mathrm{k}}=$ pengaruh kolom ke-k

$€_{\mathrm{ijk}}=$ pengaruh galat karena perlakuan ke-i, baris ke-j, dan kolom ke-k

\section{HASIL DAN PEMBAHASAN}

Pengamatan pertumbuhan tanaman dilakukan pertama kali pada bulan Juni 2010 (umur 1 bulan) setelah penanaman. Data tersebut digunakan sebagai data dasar menghitung pertumbuhan tanaman di pengukuran selanjutnya. Pengamatan kedua dilakukan pada umur 7 bulan (Desember 2010).

Parameter yang diamati adalah persentase hidup tanaman, tinggi, dan diameter batang tanaman mimba. Pengamatan selanjutnya dilakukan pada umur 1,2 , dan 3 tahun dengan parameter yang sama. Pertumbuhan dihitung berdasarkan selisih tinggi atau diameter pada pengamatan tertentu dengan pengamatan pertama. Data hasil analisa pertumbuhan ditampilkan dalam tabel 1, 2, dan 3 . 
Tabel 1. Persentase hidup tanaman mimba selama 3 tahun di Nusa Penida Table 1. Survival rate of neem for three years in Nusa penida, Bali

\begin{tabular}{|c|c|c|c|c|}
\hline \multirow{2}{*}{$\begin{array}{l}\text { Perlakuan } \\
\text { (treatment) }\end{array}$} & \multicolumn{4}{|c|}{$\begin{array}{l}\text { Pertumbuhan tinggi } \\
\text { (hight growth) } \\
\text { (cm) }\end{array}$} \\
\hline & $\begin{array}{c}7 \text { bulan } \\
\text { (7 month old) }\end{array}$ & $\begin{array}{c}1 \text { tahun } \\
\text { (1 years old) }\end{array}$ & $\begin{array}{c}3 \text { tahun } \\
(2 \text { years old })\end{array}$ & $\begin{array}{c}3 \text { tahun } \\
\text { (3years old) }\end{array}$ \\
\hline P1 & $12,00 \mathrm{a}$ & 20,64ab & 35,39 & 61,54 \\
\hline P2 & $9,24 a b$ & $15,27 a b$ & 32,71 & 62,73 \\
\hline P3 & $15,77 a$ & $24,77 a$ & 44,37 & 80,84 \\
\hline P4 & $6,68 b$ & 14,21ab & 26,38 & 32,81 \\
\hline P0 & $3,18 b$ & $5,17 \mathrm{~b}$ & 20,60 & 42,10 \\
\hline $\begin{array}{l}\text { Rata-rata } \\
\text { (average) }\end{array}$ & 9,37 & 16,01 & 31,89 & 56,00 \\
\hline
\end{tabular}

Keterangan (remark) : huruf yang sama menunjukkan tidak ada perbedaan yang signifikan (the same letter means nosignifinantly difference)

Hasil analisa data pertumbuhan tinggi dan diameter ditampilkan dalam tabel 2 dan 3. Analisa varian hanya dilakukan pada pertumbuhan 6 bulan dan 1 tahun saja, sedangkan pada pertumbuhan 2 tahun dan 3 tahun tidak memungkinkan dilakukan analisa varian.
Beberapa permasalahan yang dihadapi adalah terdapat kematian yang mengakibatkan beberapa plot tidak memungkinkan untuk dianalisa secara latin square. Oleh karena itu pertumbuhan 2 tahun dan 3 tahun dianalisa secara deskriptif yaitu dengan membandingkan rata-rata pertumbuhannya.

Tabel 2. Pertumbuhan tinggi tanaman mimba selama tiga tahun

Table 2. Hight growth of neem for three years

\begin{tabular}{lcccc}
\hline Perlakuan & \multicolumn{4}{c}{$\begin{array}{c}\text { Pertumbuhan diameter pada umur setelah tanam } \\
\text { (diametre } \begin{array}{c}\text { growth at the time }) \\
(\mathrm{mm})\end{array}\end{array}$} \\
\cline { 2 - 5 } & $\begin{array}{c}\text { 7 bulan setelah } \\
\text { tanam } \\
(7 \text { months old })\end{array}$ & $\begin{array}{c}\text { satu tahun setelah } \\
\text { tanam } \\
(1 \text { year old })\end{array}$ & $\begin{array}{c}\text { dua tahun setelah } \\
\text { tanam } \\
(2 \text { years old })\end{array}$ & $\begin{array}{c}\text { tiga tahun setelah } \\
\text { tanam } \\
\text { (3 years old })\end{array}$ \\
\hline P1 & $0,92 \mathrm{ab}$ & $1,55 \mathrm{a}$ & 3,50 & 6,15 \\
P2 & $0,87 \mathrm{ab}$ & $1,02 \mathrm{a}$ & 3,24 & 7,35 \\
P3 & $1,30 \mathrm{a}$ & $2,19 \mathrm{a}$ & 5,54 & 9,08 \\
P4 & $0,70 \mathrm{ab}$ & $1,13 \mathrm{a}$ & 3,33 & 3,59 \\
P0 & $0,44 \mathrm{~b}$ & $0,70 \mathrm{a}$ & 2,94 & 4,92 \\
\hline Rata-rata & 0,84 & 1,32 & 3,71 & 6,22 \\
(average $)$ & & & & \\
\hline
\end{tabular}

Keterangan (remark) : huruf yang sama menunjukkan tidak ada perbedaan yang signifikan (the same letter means no signifinantly difference) 
Tabel 3. Pertumbuhan diameter tanaman mimba selama tiga tahun Table 3. Diametre growth of neem for three years

\begin{tabular}{|c|c|c|c|c|}
\hline \multirow{2}{*}{$\begin{array}{l}\text { Perlakuan } \\
\text { (Treatment) }\end{array}$} & \multicolumn{4}{|c|}{$\begin{array}{l}\text { Pertumbuhan diameter pada umur setelah tanam } \\
\text { (diametre growth at the time) } \\
\text { (mm) }\end{array}$} \\
\hline & $\begin{array}{l}7 \text { bulan setelah } \\
\text { tanam } \\
\text { (7 months old) }\end{array}$ & $\begin{array}{c}\text { satu tahun setelah } \\
\text { tanam } \\
(1 \text { year old }) \\
\end{array}$ & $\begin{array}{c}\text { dua tahun setelah } \\
\text { tanam } \\
\text { (2 years old })\end{array}$ & $\begin{array}{l}\text { tiga tahun setelah } \\
\text { tanam } \\
\text { ( } 3 \text { years old })\end{array}$ \\
\hline P1 & 0,92ab & $1,55 a$ & 3,50 & 6,15 \\
\hline P2 & 0,87ab & $1,02 \mathrm{a}$ & 3,24 & 7,35 \\
\hline P3 & 1,30a & $2,19 a$ & 5,54 & 9,08 \\
\hline P4 & 0,70ab & 1,13a & 3,33 & 3,59 \\
\hline P0 & $0,44 b$ & $0,70 \mathrm{a}$ & 2,94 & 4,92 \\
\hline $\begin{array}{l}\text { Rata-rata } \\
\text { (average) }\end{array}$ & 0,84 & 1,32 & 3,71 & 6,22 \\
\hline
\end{tabular}

Keterangan (remark) : huruf yang sama menunjukkan tidak ada perbedaan yang signifikan (the same letter means nosignifinantly difference)

Data pertumbuhan tanaman mimba di Nusa Penida selama 3 tahun pengamatan seperti dalam tabel 1, 2, dan 3 memiliki beberapa kecenderungan. Kecenderungan yang pertama adalah pertumbuhan tinggi dan diameter dengan perlakuan P3 (pupuk kandang+hydrogel) memiliki tingkat pertumbuhan paling besar dibandingkan yang lain. Kecenderungan yang kedua adalah ratarata pertumbuhan tanaman pada perlakuan penambahan pupuk kandang (P1, P2, dan P3) selalu lebih besar daripada perlakuan tanpa pupuk kandang dan kontrol (P4 dan P0). Kecenderungan ketiga adalah persentase hidup perlakuan yang diberikan cenderung tidak berbeda terhadap kontrol.

Adanya ketersediaan unsur hara dan air bagi tanaman mimba dianggap sebagai faktor yang mengakibatkan pertumbuhan tanaman pada perlakuan P3 lebih besar daripada yang lain. Pupuk kandang merupakan pupuk organik yang mampu menyediakan unsur hara bagi tanaman. Pupuk kandang mempunyai kandungan unsur hara yang relatif lebih kecil namun lebih lengkap jenis haranya.

Menurut Rosmarkam \& Yuwono (2002) pupuk kandang sapi mengandung unsur hara N, P, K, $\mathrm{Ca}, \mathrm{Mg}, \mathrm{S}, \mathrm{Fe}, \mathrm{B}, \mathrm{Cu}, \mathrm{Mn}$, dan Z. Hydrogel mempunyai kemampuan menyimpan air hingga 400 kali massa dan mampu bertahan hingga 2-3 bulan (Rahardjo, 2007). Oleh karena itu tanaman akan tetap mampu tumbuh dengan baik meskipun pada kondisi yang kering atau panas. Hasil ini juga sesuai dengan penelitian Setiawan et al., (2013) yang menyatakan bahwa pemberian pupuk kandang dan hydrogel mampu meningkatkan pertumbuhan tanaman mimba di Sumbawa. Penyediaan hara bagi tanaman melalui tiga mekanisme yaitu aliran massa, diffusi dan intersepsi akar.

Hara tanaman akan bergerak bersama gerakan massa air menuju akar tanaman akibat transpirasi tanaman. Pada saat penyerapan unsur hara tanaman dari larutan tanah, terdapat beberapa unsur hara lain yang bergerak akibat diffusi yaitu pergerakan dari bagian berkonsentrasi tinggi ke rendah. Pertumbuhan akar tanaman yang terus memanjang akan mengakibatkan jarak keberadaan unsur hara semakin dekat dan lebih cepat diserap Rosmarkam \& Yuwono (2002). Tanaman menyerap unsur hara dalam bentuk ion-ion baik berupa ion positif maupun negatif seperti NH4+, NO3-, H2PO4- dll. Selain sebagai pelarut hara dan pembawa hara bagi tanaman, air juga berperan sebagai sumber hara terutama unsur H (Hardjowigeno, 1987). 
Mekanisme penyerapan hara tersebut membuktikan bahwa kehadiran air dan pupuk kandang dapat menjamin tanaman mampu terus tumbuh dengan baik.

Berdasarkan data curah hujan (Tabel 5), pada tahun 2010 terdapat beberapa bulan tanpa kejadian hujan. Hujan tidak turun di bulan Juni dan Juli kemudian bulan Agustus dan September hujan kembali turun. Pada kondisi ini, tanaman-tanaman mimba dalam plot perlakuan pemberian hydrogel akan tetap tercukupi pasokan airnya yang berasal dari simpanan hydrogel.
Kemampuan hydrogel yang mampu menahan air hingga 2-3 bulan akan membantu penyedian hara tanaman, sehingga tanaman akan dapat terus tumbuh dengan baik. Hal ini menjadikan tanaman dalam perlakuan P3 (pupuk kandang+hydrogel) memiliki pertumbuhan yang paling baik diantara yang lain. permeabilitas, porositas, struktur tanah, daya menahan air dan kation-kation tanah (Hardjowigeno, 1987).

\section{Tabel 4. Data hasil analisa sifat kimia tanah di lokasi penelitian}

\begin{tabular}{|c|c|c|c|c|}
\hline \multirow{2}{*}{$\begin{array}{l}\text { Parameter } \\
\text { (parametre) }\end{array}$} & \multicolumn{2}{|c|}{$\begin{array}{l}\text { Kondisi awal } \\
\text { (early condition) }\end{array}$} & \multicolumn{2}{|c|}{$\begin{array}{l}7 \text { bulan setelah tanam } \\
\text { (7 month after planting) }\end{array}$} \\
\hline & $\begin{array}{l}\text { Nilai } \\
\text { (value) }\end{array}$ & $\begin{array}{c}\text { Harkat* } \\
\text { (level classification)* }\end{array}$ & $\begin{array}{l}\text { Nilai } \\
\text { (value) }\end{array}$ & $\begin{array}{c}\text { Harkat* } \\
\text { (level classification)* }\end{array}$ \\
\hline $\mathrm{pH} \mathrm{H} 2 \mathrm{O}$ & 8,5 & agak alkalis & 7,8 & agak alkalis \\
\hline C organik (\%) & 2,0 & rendah & 3,0 & sedang \\
\hline $\mathrm{N}$ total (\%) & 0,2 & rendah & 0,3 & sedang \\
\hline P tersedia (ppm) & 0,3 & sangat rendah & 10,0 & sedang \\
\hline $\mathrm{K}(\mathrm{cmol} / \mathrm{kg})$ & 0,1 & rendah & 1,6 & sangat tinggi \\
\hline $\mathrm{Na}(\mathrm{cmol} / \mathrm{kg})$ & 2,2 & sangat tinggi & 7,4 & sangat tinggi \\
\hline $\mathrm{Ca}(\mathrm{cmol} / \mathrm{kg})$ & 5,0 & rendah & 30,0 & sangat tinggi \\
\hline $\mathrm{Mg}(\mathrm{cmol} / \mathrm{kg})$ & 4,0 & tinggi & 4,0 & tinggi \\
\hline Fe (ppm) & 2,0 & rendah & 5,0 & sedang \\
\hline Mn (ppm) & 8,0 & sedang & 61,0 & sangat tinggi \\
\hline Cu (ppm) & 2,6 & cukup & 12,9 & cukup \\
\hline $\mathrm{Zn}$ (ppm) & 0,9 & marginal & 3,5 & cukup \\
\hline $\mathrm{KTK}(\mathrm{cmol} / \mathrm{kg})$ & 11,0 & rendah & 25,0 & tinggi \\
\hline
\end{tabular}

Keterangan (remark) : *klasifikasi berdasarkan (classification taken from)(Sulaeman, Suparto \& Eviati, 2005)

Kecenderungan kedua dari data Tabel 2 dan 3 adalah besarnya rata-rata pertumbuhan tinggi dan diameter pada perlakuan dengan penambahan pupuk kandang selalu lebih besar daripada tanpa penambahan. Hal ini berhubungan dengan kemampuan pupuk kandang dalam meningkatkan kandungan unsur hara tanaman di dalam tanah. Data analisa tanah dalam Tabel 4 menunjukkan bahwa terjadi peningkatan harkat kesuburan tanah setelah penambahan pupuk kandang daripada kondisi awal tanah. Unsur-unsur hara tersebut sangat diperlukan tanaman dalam pertumbuhannya seperti $\mathrm{Ca}, \mathrm{Fe}, \mathrm{Mn}$ dan terutama yang berguna dalam pertumbuhan vegetatif tanaman yaitu $\mathrm{N}$ dan $\mathrm{P}$ serta yang berperan dalam pertumbuhan akar yaitu unsur K (Hardjowigeno, 1987).

Selain menambah unsur hara tanah, pupuk kandang juga mempunyai sifat mampu memperbaiki sifat fisik tanah seperti permeabilitas, porositas, struktur tanah, daya 
menahan air dan kation-kation tanah (Hardjowigeno, 1987). Menurut Mowidu (2001) tambahan input pupuk kandang sebanyak 75 ton/ha per tahun selama 6 tahun berturut-turut dapat meningkatkan 4\% porositas tanah, 14,5\% volume udara tanah pada keadaan kapasitas lapangan dan 33,3\% bahan organik serta menurunkan kepadatan tanah sebanyak 3\%. Hal ini menjadi sangat menentukan bagi tanah seperti di Nusa Penida yang cenderung memiliki kedalaman tanah yang dangkal. Dengan adanya pupuk kandang akan menambah massa tanah yang dapat digunakan sebagai tempat berkembangnya akar tanaman. Kondisi tanah di lokasi penanaman cenderung didominasi bebatuan yang tertutupi lapisan tanah tipis dan hanya dibeberapa titik yang lebih tebal. Dengan kondisi tersebut tentu dengan adanya penambahan pupuk kandang akan memberikan pengaruh yang besar bagi pertumbuhan tanaman dan terlihat sebagaimana tersaji dalam Tabel 2 dan 3.
Tekstur tanah di lokasi penelitian didominasi fraksi pasir sehingga menyebabkan tingginya tingkat infiltrasi dan permeabilitas karena dominasi pori makro dalam tanah. Berdasarkan peta tanah skala tinjau 1:250.000 Propinsi Bali, tanah di lokasi penelitian termasuk jenis mediteran coklat kemerahan. Tanah mediteran adalah tanah yang terbentuk dari pelapukan batuan kapur keras (limestone), dan bersifat tidak subur. Hasil pengamatan sifat fisika tanah satu tahun setelah tanam menunjukkan adanya penurunan nilai infiltrasi dan permeabilitas tanah pada perlakuan penambahan pupuk kandang (P1, P2, dan P3) dibandingkan plot kontrol (P0), sedangkan porositas maupun kerapatan isi tanah tidak banyak mengalami perubahan (Narendra et al. 2011). Kondisi ini menggambarkan adanya perbaikan kondisi tanah di lokasi penelitian secara fisik akibat adanya penambahan pupuk kandang meskipun belum signifikan perubahannya.

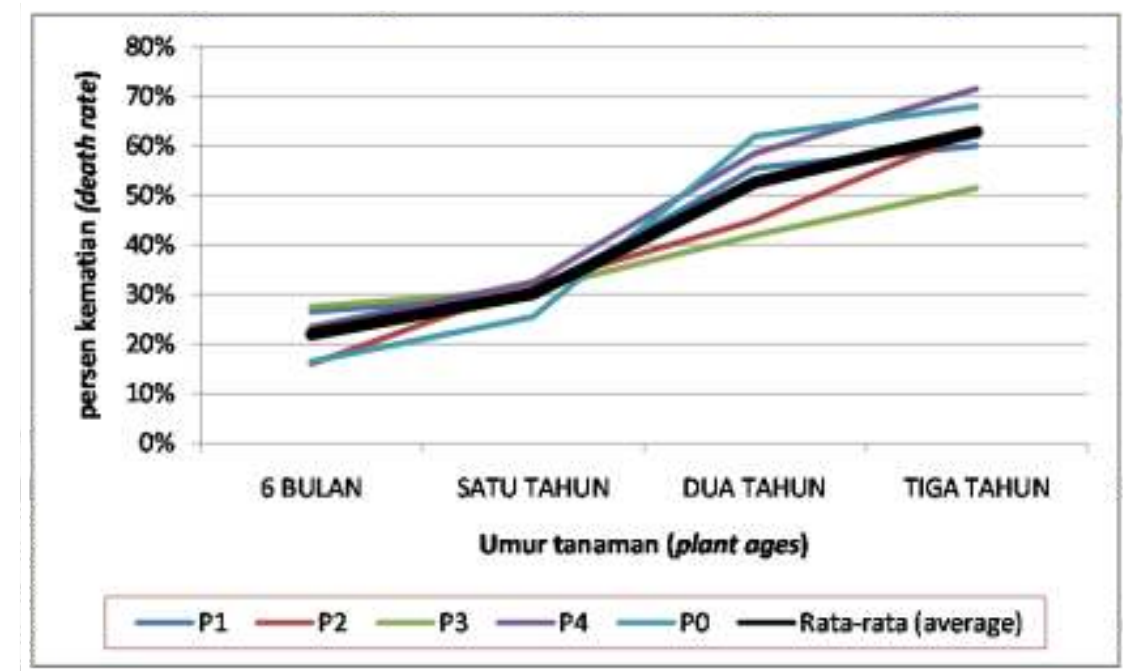

Gambar 2. Grafik kematian tanaman mimba selama pengamatan Picture 2. Death rate of the neem when observation

Prosentase hidup tanaman mimba cenderung mengalami penurunan seiring umur tanamannya. Setahun pertama persentase hidup tanaman mengalami penurunan yang cukup besar yaitu sebesar 30\%, kemudian sebesar 23\% ditahun berikutnya dan 10\% ditahun terakhir pangamatan seperti yang tergambar dalam Gambar 2. Penanaman mimba dilakukan pada bulan Mei 2010 yang merupakan akhir dari musim hujan awal tahun. Setelah ditanam, hujan tidak lagi turun dilokasi penelitian selama dua bulan (Juni dan Juli) sehingga masa proses penyesuaian diri tanaman terhadap lingkungan yang baru menjadi cukup berat. 
Hal ini yang dianggap sebagai faktor penyebab kematian tanaman mimba diawal penanaman. Namun demikian pada bulan Agustus dan September hujan mulai turun lagi sehingga tanaman mimba yang berhasil bertahan hidup pada masa penyesuaian diri akan dapat kembali bertahan dan tumbuh. Disisi lain dengan adanya hujan di bulan Agustus dan September mengakibatkan perbedaan persentase tanaman mimba yang hidup diantara perlakuan tidak berbeda secara signifikan. Antara bulan Juni hingga September dilokasi penelitian jarang sekali terjadi hujan, namun berdasarkan data BMKG Kabupaten Klungkung pada tahun 2010 secara keseluruhan di Nusa Penida mengalami hujan di sepanjang tahun meskipun dengan curah hujan yang beragam (Gambar 3).

Pada pengamatan tahun kedua mulai terlihat adanya perbedaan prosentase hidup tanaman diantara perlakuan manipulasi lingkungan serta kontrol. Namun dari Tabel 1 terlihat hanya perlakuan P2 dan P3 yang secara signifikan berbeda dengan kontrol. Pengamatan tahun ketiga kembali menunjukkan rata-rata prosentase hidup antar perlakuan manipulasi tidak berbeda secara nyata. Seperti pada pertumbuhan tinggi diameternya, pada prosentase hidup terlihat bahwa perlakuan dengan penambahan pupuk kandang cenderung memiliki rata-rata persentase hidup yang lebih besar daripada perlakuan tanpa penambahan pupuk kandang. Hal ini menegaskan bahwa pupuk kandang cukup penting dan menentukan bagi pertumbuhan tanaman pada lahan seperti di Nusa Penida. Kematian tanaman mimba banyak terjadi pada tanaman-tanaman yang memiliki pertumbuhan dibawah rata-rata. Terdapat beberapa tanaman yang mengalami stagnan atau pertumbuhannya sangat lambat dan saat musim kering tanaman tersebut banyak mengalami kematian. Daun-daunnya berubah warna menjadi kekuningan kemudian rontok dan akhirnya mati. Selama tiga tahun pengamatan dari bulan April 2010 hingga April 2013 (37 bulan) di lokasi penelitian telah terjadi 19 bulan kering dan 12 kali bulan basah (Tabel 5). Pada kondisi tersebut, hanya tanamantanaman mimba yang telah tumbuh besar dan mempunyai perakaran kuat yang akan mampu bertahan hidup dengan baik.

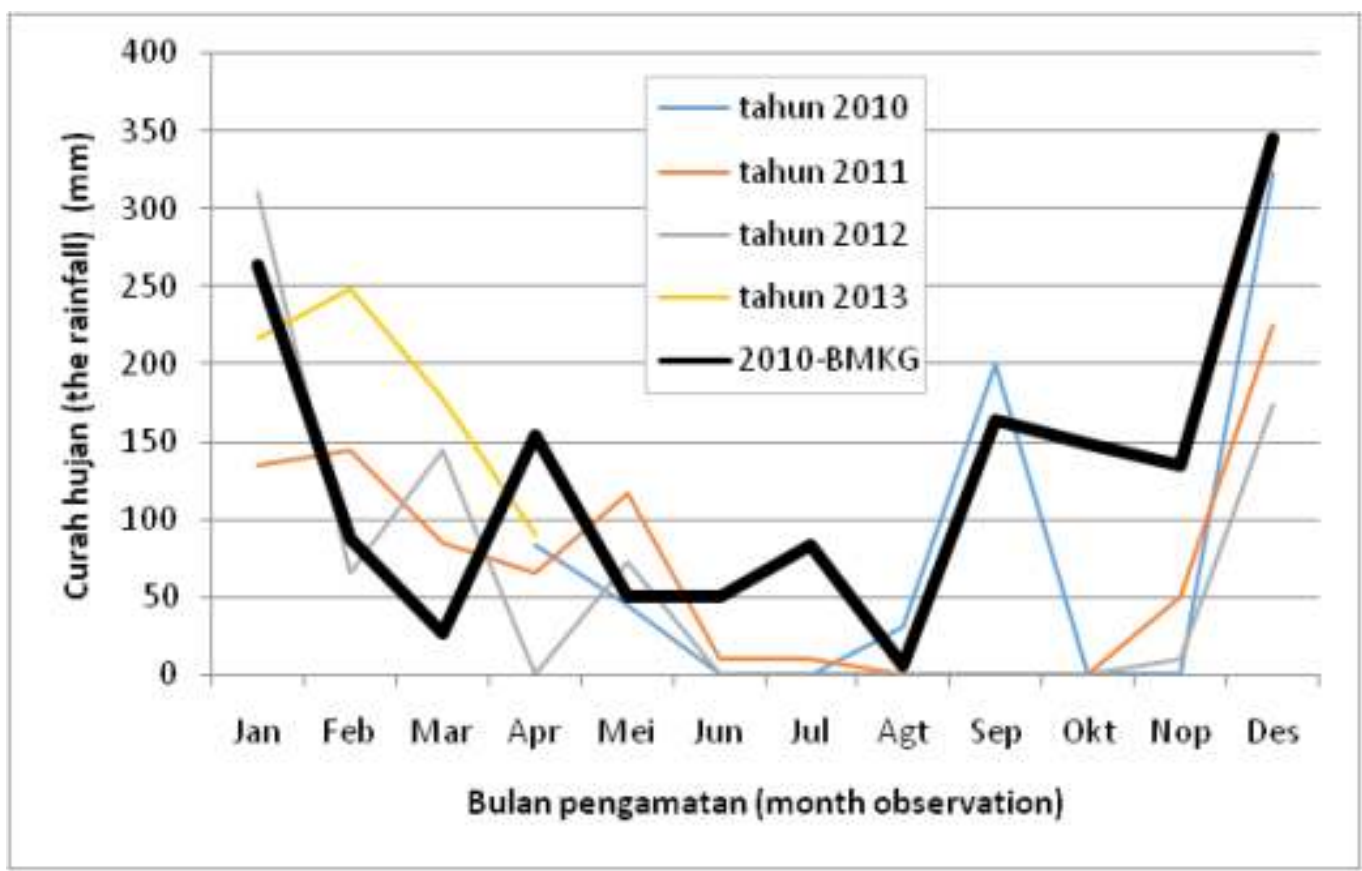

Gambar 3. Grafik kematian tanaman mimba selama pengamatan Picture 3. Death rate of the neem when observation 
Tabel 5. Data curah hujan di lokasi penelitian selama tiga tahun

Table 5. Data of rainfall for three years in the research site

\begin{tabular}{|c|c|c|c|c|c|c|c|c|}
\hline \multirow[b]{3}{*}{$\begin{array}{l}\text { Bulan } \\
\text { (month) }\end{array}$} & \multicolumn{8}{|c|}{ Tahun (years) } \\
\hline & \multicolumn{2}{|c|}{2010} & \multicolumn{2}{|c|}{2011} & \multicolumn{2}{|c|}{2012} & \multicolumn{2}{|c|}{2013} \\
\hline & $\begin{array}{c}\text { curah } \\
\text { hujan } \\
\text { (rainfall) } \\
\text { (mm) }\end{array}$ & $\begin{array}{c}\text { hari } \\
\text { hujan } \\
\text { (day with } \\
\text { rain) }\end{array}$ & $\begin{array}{c}\text { curah } \\
\text { hujan } \\
\text { (rainfall) } \\
\text { (mm) }\end{array}$ & $\begin{array}{c}\text { hari } \\
\text { hujan } \\
\text { (day with } \\
\text { rain) }\end{array}$ & $\begin{array}{c}\text { curah } \\
\text { hujan } \\
\text { (rainfall) } \\
\text { (mm) }\end{array}$ & $\begin{array}{c}\text { hari } \\
\text { hujan } \\
\text { (day with } \\
\text { rain) }\end{array}$ & $\begin{array}{c}\text { curah } \\
\text { hujan } \\
\text { (rainfall) } \\
\text { (mm) }\end{array}$ & $\begin{array}{c}\text { hari } \\
\text { hujan } \\
\text { (day with } \\
\text { rain) }\end{array}$ \\
\hline Jan & & & 135 & 6 & 311 & 7 & 217 & 18 \\
\hline Feb & & & 145 & 7 & 65 & 1 & 248 & 13 \\
\hline Mar & & & 85 & 3 & 145 & 11 & 178 & 10 \\
\hline Apr & 83 & 4 & 65 & 5 & 0 & 0 & 91 & 6 \\
\hline Mei & 45 & 3 & 116 & 6 & 72 & 2 & & \\
\hline Jun & 0 & 0 & 10 & 1 & 0 & 0 & & \\
\hline Jul & 0 & 0 & 10 & 1 & 0 & 0 & & \\
\hline Agt & 30 & 2 & 0 & 0 & 0 & 0 & & \\
\hline Sep & 200 & 6 & 0 & 0 & 0 & 0 & & \\
\hline Okt & 0 & 0 & 0 & 0 & 0 & 0 & & \\
\hline Nop & 0 & 0 & 50 & 3 & 10 & 1 & & \\
\hline Des & 323 & 13 & 225 & 7 & 173 & 6 & & \\
\hline
\end{tabular}

Secara keseluruhan apabila dilakukan perbandingan dari ketiga perlakuan lingkungan yang digunakan yaitu pupuk kandang, hydrogel, dan gulud maka pupuk kandang adalah yang paling mempengaruhi pertumbuhan awal tanaman mimba di Nusa Penida. Ketiga bahan yang digunakan mempunyai tujuan untuk membantu tanaman menghadapi kondisi di Nusa Penida. Pupuk kandang diharapkan mampu mengatasi permasalahan kedalaman dan hara tanah yang tipis, hydrogel diharapakan mampu mengatasi persediaan air yang sedikit, dan gulud diharapkan mampu mengurangi erosi akibat kemiringan lahan yang curam. Beberapa alasan yang dapat diajukan adalah kondisi kesuburan tanah awal memiliki harkat yang rendah sehingga meskipun ada penambahan air dari hydrogel, pengaruhnya terhadap pertumbuhan tanaman mimba akan tetap lebih kecil dibandingkan jika dilakukan penambahan unsur hara dari pupuk kandang. Alasan yang kedua adalah meskipun kimiringan lokasi penelitian curam namun hasil pengukuran erosi permukaan yang terjadi masih dibawah standar erosi terbolehkan, sehingga pemberian gulud tidak cukup besar pengaruhnya terhadap pertumbuhan mimba daripada perlakuan yang tanpa diberikan gulud. Kondisi ini tergambar dalam Tabel 2 dan 3 dimana perlakuan P4 hampir selalu lebih kecil pertumbuhannya dibandingkan perlakuan P1, P2, dan P3.

Rata-rata pertumbuhan tanaman mimba hingga akhir pengamatan adalah tinggi $56 \mathrm{~cm}$ (Tabel 2) dan diameter 6,2 mm (Tabel 3). Sedangkan untuk tinggi tanaman rata-rata hingga tahun ketiga adalah 42,6-91,2 cm dan diamater 5,6-10,8 mm. Kondisi ini sebenarnya masih jauh dengan hasil penelitian Ahmad \& Idris, (2007) dimana pertumbuhan mimba pada tahun ketiga penanaman bisa mencapai tinggi 4-7 m. Hasil ini juga masih dibawah rata-rata pertumbuhan tanaman mimba di Sumbawa yaitu tinggi sebesar 213,4-299,5 cm dan diameter 26,0-36,3 mm (Setiawan et al., 2013). Perbedaan kondisi lahan di kedua lokasi tersebut dianggap sebagai faktor yang cukup berpengaruh. Kondisi kedalaman tanah dikedua lokasi tersebut cenderung lebih baik daripada di Nusa Penida, sehingga tanaman mimba tentunya akan lebih mampu tumbuh lebih baik. Namun demikian dari hasil 
ini ada beberapa hal yang dapat dijadikan dasar pertimbangan untuk kegiatan selanjutnya yaitu penggunaan pupuk kandang menjadi faktor yang penting untuk penanaman pada kondisi tanah dangkal seperti yang ada di Nusa Penida. Penggunaan pupuk kandang dapat juga dikombinasikan dengan hydrogel agar pertumbuhan tanaman lebih baik terutama pada kondisi lokasi dengan kecenderungan cuaca yang kering. Di beberapa daerah seperti Jawa Barat dan Lampung, hydrogel sudah mulai juga digunakan untuk menanggulangi masalah kekeringan (Kartosoewarno, 2006).

\section{KESIMPULAN DANSARAN}

Terdapat peningkatan pertumbuhan tanaman mimba akibat adanya kegiatan manipulasi lingkungan yang diberikan. Perlakuan manipulasi lingkungan dengan pemberian pupuk kandang+hydrogel memiliki peningkatan pertumbuhan tanaman mimba paling besar dibandingkan yang lain yaitu dua kali lipat dibandingkan kontrol.

\section{UCAPAN TERIMA KASIH}

Ucapan terima kasih kepada Balai Penelitian Pengembangan Teknologi Hasil Hutan Bukan Kayu dikarenakan penelitian ini merupakan bagian kegiatan DIPA anggaran balai tahun 2010 hingga 2013. Terima kasih juga kepada bapak Lalu Gde Wiryadi dan bapak I Putu Adnyana (Suana) yang telah banyak membantu pelaksanaan kegiatan dilapangan sehingga berjalan dengan lancar.

\section{DAFTAR PUSTAKA}

Ahmad, S., \& Idris, S. (1997). Azadirachta indica A.H.L. Juss. Retrieved January 5, 2011, from. http:// www.proseanet.org

Arsyad, S. (2010). Konservasi Tanah dan Air. Bogor: IPB Press.

Hardjowigeno, S. (1987). ilmu kesuburan tanah (pertama). Jakarta: PT.
Mediyatama Sarana Perkasa.

Indoneem. (2005). PT. Intaran Indonesia. Retrieved December 5, 2013, from http://www.indoneem.com/cms5/index. php?option=com_content\&view $=$ article \&id $=57 \&$ Itemid $=68$

Kartosoewarno, S. (2006). Hydrogel. Bogor: Kuntum Nurseries.

Mowidu. (2001). Peranan Bahan Organik dan Lempung Terhadap Agregasi dan Agihan Ukuran Pori pada Entisol. Universitas Gadjah Mada.

Narendra, B. H., Nandini, R., \& Setyayudi, A. (2011). Ujicoba teknik manipulasi lingkungan dalam rehabilitasi lahan kritis dengan jenis mimba di Nusa Penida, Bali. Mataram.

Pemerintah Propinsi bali. (2010). Laporan Status Lingkungan Hidup Daerah ProvinsiBali.

Pemerintah Propinsi Bali. (2010). Topographi propinsi Bali. Retrieved January 5, 2012, $\mathrm{f} \quad \mathrm{r} \quad \mathrm{o} \quad \mathrm{m}$ http://www.baliprov.go.id/id/Topographi Rahardjo, S. (2007). Hydrogel Merupakan Salah Satu Teknologi untuk Mengatasi Lahan Kering di Nusa Tenggara Barat. Retrieved December 16, 2013, from http://ntb.litbang.deptan.go.id/2007/SP/ hydrogel.doc

Rosmarkam, A., \& Yuwono, N. W. (2002). Ilmu Kesuburan Tanah. Yogyakarta: penerbit kanisius.

Sastrosupadi. (2000). Rancangan Percobaan Praktis Bidang Pertanian (revisi). Yogyakarta: penerbit kanisius.

Setiawan, O., Samawandana, G., \& Sari, D. S. P. (2013). Ujicoba penyiapan lahan dalam mendukung keberhasilan penanaman mimba di sumbawa. mataram.

Sulaeman, Suparto, \& Eviati. (2005). Petunjuk Teknis Analisis Kimia Tanah, Tanaman, Air, Dan Pupuk. bogor: Balai Penelitian Tanah, Badan Penelitian dan Pengembangan Pertanian, Departemen Pertanian. 